\title{
PENERAPAN MODEL KOOPERATIF TIPE-GROUP INVESTIGATION (GI) PADA MATERI SISTEM EKSKRESI MANUSIA UNTUK MENINGKATKAN HASIL BELAJAR SISWA KELAS XI IPA SMA N 8 KOTA BENGKULU
}

\author{
Een Suci Febrianti ${ }^{1 *}$, Bhakti Karyadi, ${ }^{1}$, Kasrina ${ }^{1}$ \\ ${ }^{1}$ Program Studi Pendidikan Biologi, Fakultas Keguruan dan Ilmu Pendidikan, Universitas Bengkulu \\ Email: eensucifebrianti14@gmail.com
}

\begin{abstract}
Abstrak
Penelitian ini bertujuan untuk mendeskripsikan tentang aktivitas dan hasil belajar siswa di kelas XI SMA Negeri 08 Kota Bengkulu dan mendeskripsikan proses pembelajaran Biologi dengan model kooperatif tipe Group Invetigation pada materi sistem ekskresi manusia. Jenis penelitian ini adalah penelitian tindakan kelas (PTK) yang dilakukan dalam dua siklus. Setiap siklus terdiri atas empat tahap yaitu perencanaan, pelaksanaan, observasi, dan refleksi. Metode dalam penelitian ini adalah deskriptif. Subjek penelitian ini adalah guru biologi dan seluruh siswa kelas SMA Negeri 08 Kota Bengkulu tahun ajaran 2016/2017. Instrumen yang digunakan untuk mengumpulkan data yaitu lembar observasi dan lembar tes. Hasil penelitian menunjukkan bahwa aktivitas guru dan siswa pada siklus I berkategori cukup dan meningkat di siklus II menjadi kategori baik. hasil belajar kognitif siswa pada siklus I termasuk kriteria belum tuntas dengan persentase ketuntasan klasikal $56,6 \%$, namun pada siklus II meningkat menjadi $76,6 \%$ dengan kriteria tuntas. Maka dapat disimpulkan bahwa model pembelajaran kooperatif tipe Group Investigation dapat meningkatkan aktivitas dan hasil belajar siswa di kelas VIII ${ }_{2}$ SMP Negeri 03 Kota Bengkulu.

Kata kunci: Hasil Belajar, Model Kooperatif tipe Group Investigation, Aktivitas Guru dan Siswa
\end{abstract}




\section{PENDAHULUAN}

Biologi merupakan ilmu pengetahuan alam yang mempelajari tentang kehidupan dari segala aspek. Pembelajarn biologi bukan hanya sebagai penguasaan kumpulan pengetahuan yang berupa fakta, konsep atau prinsip, tetapi juga merupakan suatu proses penemuan. Pembelajaran Biologi di SMA diharapkan dapat menjadi wahana bagi siswa untuk mempelajari diri sendiri dan alam sekitar, serta prospek pengembangan lebih lanjut dalam penerapan di dalam kehidupannya sehari-hari.

Berdasarkan hasil wawancara terhadap siswa kelas XI IPA SMAN 8 Kota Bengkulu, siswa merasa pembelajaran biologi dianggap sulit untuk dipahami karena guru lebih banyak memberikan tugas yang harus diselesaikan secara mandiri oleh siswa. Siswa lebih senang jika pembelajaran itu dilakukan secara diskusi. Guru juga masih menggunakan metode ceramah sehingga pembelajaran masih berpusat kepada guru.

Selama proses pembelajaran berlangsung guru hanya menyampaikan materi pembelajaran, sehingga siswa kurang merespon pelajaran dan hanya beberapa siswa yang terlibat aktif mengemukakan pendapat yang disampaikan oleh guru, beberapa siswa ribut dan melakukan aktivitas diluar pembelajaran seperti mengobrol dengan teman sebangku saat pembelajaran berlangsung,

Penggunaan metode pembelajaran yang telah dilakukan guru ternyata belum mampu mendorong terciptanya situasi belajar yang berpusat pada siswa baik secara invidu maupun kelompok hal ini menyebabkan rendahnya hasil belajar siswa dalam pembelajaran biologi. Hasil belajar siswa dikatakan tuntas secara klasikal apa bila mencapai KKM yaitu $\geq 75$. Hasil wawancara terhadap guru biologi, diperoleh informasi bahwa masih terdapat 50\% siswa yang memperoleh nilai di bawah kriteria ketuntasan minimal (KKM) pada ulangan tengah semester di kelas XI IPA. Rendahnya hasil belajar biologi ini juga dipengaruhi oleh rendahnya keterlibatan siswa dalam proses pembelajaran dengan kata lain masih banyaknya siswa yang kurang aktif.

Berdasarkan permasalahan tersebut, perlu dilakukan upaya peningkatan perbaikan proses pembelajaran yang melibatkan siswa dalam pembelajaran. Pada penelitian ini peneliti akan mengambil materi Sistem Ekskresi, hal ini dikarenakan pada materi ini terdapat kegiatan yang menuntut kerja sama dan investigasi yang baik dalam proses pembelajaran. Salah satu strategi untuk meningkatkan hasil belajar siswa pada materi sistem ekskresi ini yaitu model pembelajaran Kooperatif-tipe Group Investigantion. Tujuan dari pembelajaran kooperatif adalah 1) meningkatkan hasil belajar siswa, 2) siswa menghargai satu sama lain, 3) pengembangan keterampilan siswa (Spencer, 2009).

Model pembelajaran Kooperatif mempunyai cukup banyak tipe atau varian, salah satu tipe dari Kooperatif yaitu tipeGroup Investigation (Johnson, dkk, 2000). Group investigation (GI) adalah kelompok kecil untuk menuntun dan mendorong siswa dalam keterlibatan belajar. Model ini menuntut siswa untuk memiliki kemampuan yang baik dalam berkomunikasi maupun dalam keterampilan proses kelompok, hasil akhir dari kelompok adalah sumbangan ide dari tiap anggota serta pembelajaran kelompok yang notabene lebih mengasah kemampuan intelektual siswa dibandingkan belajar secara individual (Riadi, 2012).

Berdasarkan data dan informasi diatas, maka peneliti dan guru berkerjasama untuk menggunakan model pembelajaran kooperatif tipe Group Investigation untuk meningkatkan hasil belajar siswa khususnya kelas XI IPA pada materi sistem ekskresi.

\section{METODE}

Jenis penelitian yang digunakan yaitu Penelitian Tindakan Kelas (PTK). Sedangkan metode yang digunakan dalam penelitian ini adalah metode deskriptif yang pelaksanaannya terdiri dari dua siklus. Tiap 
siklus terdiri dari empat tahapan yaitu perencanaan, pelaksanaan, observasi dan refleksi. Subjek penelitian ini adalah guru biologi dan seluruh siswa kelas SMA Negeri 8 Kota Bengkulu tahun ajaran 2016/2017 yang berjumlah 30 orang yang terdiri dari terdiri dari 9 siswa laki-laki dan 21 siswa perempuan dengan penentuan subyek secara Convenience Sampling (ketersediaan).

Teknik pengumpulan data yang digunakan dalam penelitian ini ada 2 cara, yaitu dengan observasi dan tes. Sedangkan instrumen penelitian yang digunakan adalah lembar observasi dan lembar tes. Hasil belajar siswa dianalisis dengan menggunakan rumus rerata, yaitu:

$$
X=\frac{\Sigma X}{N}
$$

(Sukardi, 2012)

Keterangan :

$\mathrm{X}=$ Nilai rata-rata skor hasil belajar

$\Sigma \mathrm{X}=$ Jumlah skor hasil belajar

$\mathrm{N} \quad=$ Jumlah siswa

Ketuntasan belajar klasikal dihitung menggunakan rumus:

$$
P=\frac{\sum X}{N} x 100 \%
$$

(Sudijono, 2014)

Keterangan :

$\mathrm{P} \quad=$ Angka persentase

$\sum X=$ jumlah siswa berkatagori tuntas/tidak tuntas

$\mathrm{N} \quad=$ jumlah seluruh siswa

Menurut ketentuan yang ditetapkan di SMA Negeri 8 Kota Bengkulu hasil belajar siswa dikatakan tuntas pada mata pelajaran IPA apabila mencapai nilai $\geq 75$.

\section{HASIL DAN PEMBAHASAN}

Berdasarkan hasil penelitian yang telah dilakukan di kelas XI IPA SMA Negeri 08 Kota Bengkulu sebanyak 2 siklus pembelajaran dengan menerapkan model pembelajaran kooperatif tipe Group Investigation pada materi sistem ekskresi, maka data observasi aktivitas guru dan siswa dapat dilihat pada Tabel 1. Sedangkan data hasil belajar siswa dapat dilihat pada Tabel 2 .

\begin{tabular}{|c|c|c|c|c|c|c|c|c|}
\hline \multirow{3}{*}{ Pengamat } & \multicolumn{4}{|c|}{ Aktivitas Guru } & \multicolumn{4}{|c|}{ Aktivitas siswa } \\
\hline & \multicolumn{2}{|c|}{ Siklus I } & \multicolumn{2}{|c|}{ Siklus II } & \multicolumn{2}{|c|}{ Siklus I } & \multicolumn{2}{|c|}{ Siklus II } \\
\hline & Skor & Kriteria & Skor & Kriteria & Skor & Kriteria & Skor & Kriteria \\
\hline 1 & 32 & Baik & 33 & Baik & 31 & Baik & 32 & Baik \\
\hline II & 31 & Baik & 32 & Baik & 29 & Baik & 31 & Baik \\
\hline Total Skor & 63 & & 65 & & 60 & & 63 & \\
\hline Rerata Skor & 31,5 & Baik & 32,5 & Baik & 30 & Baik & 31,5 & Baik \\
\hline Siklus & Rata-rat & nilai & Jumlah & wa yang $t$ & & Persenta & $\begin{array}{l}\text { ketunta } \\
\text { klasikal }\end{array}$ & $\mathrm{n}$ belajar \\
\hline$I$ & &, 66 & & 17 & & & 56 & \\
\hline II & & 6,6 & & 23 & & & 76, & \\
\hline
\end{tabular}

Tabel 1. Data Obervasi Aktivitas Guru dan Siswa Pada Siklus I dan II 
Berdasarkan hasil penelitian dengan menerapkan model pembelajaran kooperatif tipe Group Investigation (GI) pada kelas XI IPA SMA Negeri 8 Kota Bengkulu terjadi peningkatan aktivitas dan hasil belajar dari siklus I ke siklus II. Hal ini ditunjukkan dari adanya peningkatan rerata skor observasi aktivitas guru, aktivitas siswa, dan hasil belajar siswa pada siklus II. Peningkatan pembelajaran yang terjadi pada siklus II ini diperoleh karena adanya perbaikan proses pembelajaran pada siklus I. Dari peningkatan rerata skor aktivitas guru dan siswa dalam proses pembelajaran kooperatif tipe Group Investigation, maka dapat disimpulkan bahwa aktivitas guru sangat menentukan aktivitas siswa. Artinya jika aktivitas guru dalam melakukan pengajaran d ikelas baik, maka aktivitas siswa akan baik begitupun sebaliknya jika aktivitas guru dalam pengajaran kurang baik, maka aktivitas siswa akan kurang baik juga. Hasil ini juga diperkuat oleh Dimyati dan Mudjiono (2006) yang menyatakan bahwa belajar yang dihayati oleh seorang siswa ada hubungannya dengan usaha pembelajaraan, yang dilakukan oleh guru.

Berdasarkan penelitian yang telah dilakukan, terdapat kelebihan maupun kekurangan yang dirasakan peneliti selama menerapkan model pembelajaran kooperatif tipe Group Investigation didalam kelas. Kelebihan dari model yang dirasakan peneliti selam menerapkan model pembelajaran discovery learning adalah 1) siswa terlatih untuk mempertanggung jawabkan jawaban yang diberikan. 2) siswa saling bekerjasama, merencanakan dan mengorganisasikan pekerjaan. 3) mengembangkan dan melatih keterampilan. Kelemahan yang dilakukan pada model pembelajaran kooperatif tipe Group Investigation ini adalah 1) tidak semua topik cocok dengan model pembelajaran GI. 2) diskusi kelompok biasanya berjalan kurang efektif. 3) kurangnya waktu pada saat melakukan model pembelajaran ini.
Pada penelitian ini kompetensi pengetahuan dinilai melalui tes (postest) di akhir pembelajaran, berupa test tertulis dalam bentuk post test dengan kategori soal yaitu 5 soal essay. Hasil belajar siswa pada pembelajaran kooperatif tipe Group Investigation mengalami peningkatan dari siklus I ke siklus II. Pada siklus I diperoleh nilai rata-rata kelas $56,6 \%$ menjadi $76,6 \%$ pada siklus II. Peningkatan hasil belajar tersebut sejalan dengan peningkatan aktivitas guru dan siswa. Aktivitas guru dan siswa yang kurang optimal pada siklus I diperbaiki atau ditingkatkan oleh guru pada siklus II. Peningkatan aktivitas pada setiap tahapan pembelajaran kooperatif tipe Group Investigation dapat meningkatkan hasil belajar siswa.

Proses pembelajaran yang berpusat pada siswa akan mendorong siswa untuk aktif mencari dan menemukan konsep pembelajaran. Selain itu, proses pembelajaran secara berkelompok menuntut siswa untuk saling bekerjasama secara efektif dan saling melangkapi pengetahuan satu sama lain (sharing) dalam menemukan konsep pembelajaran. Hal ini sesuai dengan pendapat Kunandar (2009) bahwa hasil belajar diperoleh dari "sharing" antar teman, antar kelompok, dan antar siswa yang sudah tahu dan yang belum tahu. Sehingga pelaksanaan proses pembelajaran dengan model kooperatif tipe Group Investigation secara optimal dapat meningkatkan hasil belajar siswa.

\section{PENUTUP}

\section{Simpulan}

Simpulan dari penelitian ini adalah:

1) Penerapan model kooperatif tipe Group Investigation di kelas XI IPA SMAN 8 Kota Bengkulu materi sistem ekskresi dapat meningkatkan aktivitas guru dan siswa .

2) Penerapan model kooperatif-tipe Group Investigation pada 
pembelajaran biologi pada materi sistem ekskresi kelas XI IPA SMAN 8 Kota Bengkulu dapat meningkatkan hasil belajar siswa.

\section{Saran}

Guru hendaknya dapat menginovasikan pembelajaran $\mathrm{Gl}$ pada materi lainnya.

\section{DAFTAR PUSTAKA}

Dimyati dan Mudjiono. 2006. Belajar dan Pembelajaran. Jakarta: Rineka Cipta.

Johnson, R.T dan Jhonson, D.W. 1994. An overview of cooperative learning. (Online),( http://www.learnline.nrw.de/angeb ote/greenline/lernen/downloads/ov erview.pdf.) Diakses pada 7 Juni 2013.

Kunandar. 2009. Guru Profesional Implementasi Kurikulum Tingkat Satuan pendidikan (KTSP) dan Sukses Dalam Sartivikasi Guru. Jakarta: PT Raja Grafindo Persada

Riadi, M. 2012. Model Pembelajaran Group Investigation. (Online) ( http://www.kajianpustaka.com/201 2/10/model-pembelajaran-group investigation.html). Diakses tanggal 1 November 2013

Spencer Kagan. Coopoerative Learning. (Online) http://edtech.kennesaw.edu/intech/ /cooperativelearning,html). Diakses 21 Oktober 2009.

Sudijono, A. 2014. Pengantar Statistik Pendidikan. Jakarta: Rajawali Press.

Sukardi, H. M. 2012. Evaluasi Pendidikan. Jakarta: Bumi Aksara. 